IBAD Sosyal Bilimler Dergisi

IBAD Journal of Social Sciences

dergipark.org.tr/ibad

IBAD, 2021; (9): 291-310

DOI: 10.21733/ibad.844971

Derleme / Review Article

\title{
Gıda Kayıp ve İsrafının Azaltılmasında Gıda Bankacılığı
}

Food Banking in Reducing Food Loss and Waste

\author{
Mehmet Seçkin Aday ${ }^{*}$ \\ Serpil Aday ${ }^{2}$ \\ * Sorumlu yazar \\ Corresponding author
}

${ }^{1}$ Doç. Dr., Çanakkale Onsekiz Mart Üniversitesi, Mühendislik Fakültesi, Türkiye Assoc. Prof. Dr., Canakkale Onsekiz Mart University, Engineering Faculty, Turkey mseckinaday@comu.edu.tr ORCID ID 0000-0002-5669-5812

${ }^{2}$ Öğr. Gör. Dr., Çanakkale Onsekiz Mart Üniversitesi, Biga Meslek Yüksekokulu, Türkiye Lec. Dr., Canakkale Onsekiz Mart University, Biga Vocational School, Turkey serpiladay@comu.edu.tr

ORCID ID 0000-0002-2896-1191

Makale geliş tarihi / First received : 22.12.2020

Makale kabul tarihi / Accepted : : 11.01.2021

\section{Bilgilendirme / Acknowledgement:}

Yazarlar aşağıdaki bilgillendirmeleri yapmaktadırlar:

1- Makalede isim sıralaması katkı oranına göre yazılmıştır.

2- Makalenin yazarları arasında çıkar çatışması bulunmamaktadır.

3- Makalemizde etik kurulu izni ve/veya yasal/özel izin alınmasını gerektiren bir durum yoktur.

4- Bu makalede araştırma ve yayın etiğine uyulmuştur.

This article was checked by iThenticate. Similarity Index 06\%

\section{Atıf bilgisi/Citation:}

Aday, M., Aday, S. (2021). Gıda kayıp ve israfının azaltılmasında gıda bankacılığı. IBAD

Sosyal Bilimler Dergisi, (9), 291-310. 


\section{ÖZ}

Gıda tedarik zincirinin çeşitli aşamalarında meydana gelen kayıplar sebebiyle, dünyada üretilen gıdaların üçte birlik kısmı yok olmaktadır. Bu durumun neticesinde, insanlar açlık ve yetersiz beslenme ile birlikte küresel olarak çözülmesi gereken gıda kaybı ve israf sorunlarına odaklanmıştır. Kaybolan veya israf edilen gıdanın üretimi için kullanılan su, enerji, toprak, emek ve sermaye girdilerinin miktarı düşünüldüğünde, durumun önemi daha açık hale gelmektedir. Buna ek olarak gelecekte insan nüfusunun artması gidaya olan talebi de artıracaktır. Bu nedenle, tarımsal üretimin artırılması, insanlar için gerekli olan gıdanın karşılanması için bir çözüm yolu olarak görülmektedir. Fakat gıdaların üretiminde kullanılan kaynakların sınırlı olması; daha fazla üretmekten çok üretilen gıdanın korunmasına yönelik önleyici tedbirlerin alınmasına neden olmaktadır. Bu kapsamdaki çözüm yollarından bir tanesi olan gıda bankaları; işletmelerin stoklarında bulunup, çeşitli sebeplerden dolayı değerini kaybeden ve bu nedenle atılma ihtimali bulunan insan tüketimine uygun gıdaları, ihtiyacı olan insanlara ulaştırmada görev alan organizasyonlar olarak tanımlanmaktadır. Gıda bankaları bu sistem aracılığıyla hem açlık hem yoksulluk hem de israfın önlenmesine katkıda bulunmakta ve gıdaya herkesin adaletli biçimde ulaşmasını kolaylaştırmayı amaçlamaktadır. Gıda bankaları sadece yoksul tüketicilere fayda sağlamamakta, ayrıca bağış yapan şirketlere de vergi avantajı yaratmaktadır. Bu nedenle, bu makalede gida kayıp ve israfların nedenleri, kayıpların meydana geldiği gıda grupları, meydana gelen ekonomik kayıplar, gıda bankacilığının kapsamı, sağladığı avantajlar, uygulamada görülen zorluklar ve bu sorunlara ilişkin çözüm önerileri hakkında bilgi verilmektedir.

\section{Anahtar kelimeler}

Gıda kayıpları, İsraf, Gıda bankacılığı

\section{ABSTRACT}

One third of the food produced in the world has been lost due to losses occurring at various stages of the food supply chain. This situation caused people to focus on food loss and wastage problems that need to be solved globally as well as hunger and malnutrition. When considered the amount of water, energy, land, labor and capital inputs used for the production of food lost or wasted, the importance of the situation becomes clearer. Moreover, the increase in the human population in the future will increase the food demand. For this reason, increasing agricultural production is seen as a solution to meet the food required for humans. However, the fact that the resources used in the production of food are limited causes preventive measures to be taken to protect the produced food rather than producing more. One of the solutions within this scope is the food banks. Food banks are defined as organizations participating to deliver the food which is proper for human consumption, is in the stocks of businesses and loses their nutritional value due to various reasons and are likely to be disposed of to the people in need. Through this system, food banks contribute to the prevention of hunger, poverty and waste, and aim to facilitate fair access to food for everyone. Food banks not only benefit poor consumers, but also provide tax advantage for grantor companies. For this reason, this study gives information about the reasons for food loss and waste, the food groups where the losses occur, the economic losses that occur, the scope of food banking, their advantages, the difficulties seen in practice and the solution suggestions for these problems.

\section{Keywords}

Food losses, Waste, Food banking 


\section{GİRIŞ}

Resmi Gazete (RG)'de yer alan 5996 sayılı Veteriner Hizmetleri, Bitki Sağlığı, Gıda ve Yem Kanunu'na göre, gıda genel anlamda; insanların tüketimi amacıyla işlenmiş, kısmen işlenmiş veya işlenmemiş formda bulunan her türlü madde olup, doğrudan insan tüketimine sunulmayan maddeleri kapsamamaktadır (RG, 2020). Gıdalar üretimden son tüketiciye ulaşıncaya kadar çeşitli aşamalardan geçmekte ve bu aşamalar gıda tedarik zincirini oluşturmaktadır. Bu zincirde, birbiriyle etkileşime giren çok sayıda üretici, işleyici, perakendeci ve tüketici bulunmaktadır. Bu aşamalar sırasında çeşitli nedenlerle gıdalar kayıp olmakta ve bunun neticesinde de israf ekonomisi karşımıza çıkmaktadır (De Gorter, Drabik, Just, Reynolds ve Sethi, 2020, s. 1). Bu kavramlardan bir tanesi olan gıda kayıpları; son tüketiciye ulaşmadan önce gida tedarik zincirinde herhangi bir sebeple meydana gelen fireler olarak tanımlanmakta olup, gida israfı ise tüketici seviyesinde herhangi bir sebeple atılan veya bozulmaya terk edilen ürünleri içermektedir (Oral, 2015, s. 5).

Dünya nüfusunun 2050 yılına kadar 9,8 milyara ulaşacağ talebi de artacak olup, bu artş̧ı gıda tedarik sistemi üzerinde baskı oluşturacağ beklenmektedir (Withanage, Dias ve Habib, 2021, s. 2). Gıda ve Tarım Örgütü (FAO), küresel olarak her yıl 940 milyar \$ tutarında 1,3 milyar ton gıdanın kaybedildiğini veya israf edildiğini tahmin etmektedir (FAO, 2016). Yapılan araştırmalarda Türkiye' de yıllık israf edilen gidanın 26 milyon ton olduğu belirtilmekte olup, ekonomik karşılığının ise 214 milyar € olduğu düşünülmektedir. En fazla kayıp ve israf yaşanan ürün grubu ise meyve ve sebzelerdir ve üretilen yaş meyve ve sebzenin \%25-40'lık kısmı boşa gitmektedir. Ayrıca Türkiye'de günlük 4,9 milyon adet (yıllık olarak 1,7 milyar adet) ekmeğin israf edildiği bildirilmektedir (TGDF, 2020).

Dünya çapında her yıl israf edilen gıdanın boyutu ve buna bağlı olarak meydana gelen çevresel ve sosyo-ekonomik yük nedeniyle, her ülke gıda israfının azaltılmasına yönelik çalışmalar yapmaktadır (Abdulla, Martin, Gooch ve Jovel, 2013, s. 138). Bu çalışmalardan bir tanesi de Türkiye' de gerçekleştirilmekte olup, Tarım ve Orman Bakanlığı ve Gıda Tarım Örgütü (FAO) iş birliğiyle yaratılan "Gıdanı Koru, Sofrana Sahip Çık" projesi; Türkiye'de gıda kayıplarının önlenmesi, azaltılması ve yönetimine yönelik oluşturulan strateji ve eylem planını içermektedir (TOB, 2020).

Gıda kayıp ve israflarının çeşitli sebepleri bulunmakta olup bunlar; yetersiz planlama, gereğinden fazla gıdanın alınması, endüstriyel işleme sırasındaki hatalar, yönetimsel, finansal ve teknik zorluklar ve tüketici davranışları olarak sınıflandırılabilmektedir (Rohini, Geetha, Vijayalakshmi, Mini ve Pasupathi, 2020, s. 691-692). Bu nedenle, gıda kayıp ve israflarının önlenmesine yönelik tüm çalışmalar; gıda zincirindeki tüm paydaşlar için fayda sağlaması durumunda etkili olmaktadır. Bu kapsamda; üreticilere bu kayıpları azaltmak için yeterli teşvik sağlanması ve ürünlerini koydukları depolama koşullarının iyileştirilmesi, gidaları işleyen fabrikaların kaliteli ürüne ulaşımının sağlanarak, kalite standardını yerine getirmeyen ürünlerin üretiminin engellenmesi ve perakende noktalarına erişmede kullanılan nakliye koşullarının iyileştirilmesi gibi çözümler gıda kayıplarının azaltılmasını sağlayabilmektedir (Vos, 2019, s. 148-149).

Gıda kayıp ve israflarının engellenmesinde kullanılan diğer bir yol ise gıda bankalarıdır. Gıda bankalarının organize yapıları ve uygulamaları ülkeler arasında farklılık gösterse de, bu girişimler genel olarak ihtiyaç sahiplerine gıda sağlamak için, gıda bağışlarının ve gönüllülerin 
bir araya gelmesi olarak tanımlanmaktadır. Gıdalar; üreticilerden, firmalardan, perakendecilerden veya halktan gelen bağışlar yoluyla toplanmaktadır. Devletin rolü ise bu kapsamdaki faaliyetlerin kolaylaştırılmasına yöneliktir (Tarasuk, St-Germain ve Loopstra, 2020, s. 841). Gıda bankalarının gıda güvencesini destekleyici bir görevi de olup, muhtaç durumdaki insanlara uzun vadeli çözüm yerine kısa vadeli alternatifler sunma amacı da taşımaktadır (Bazerghi, McKay ve Dunn, 2016, s. 732). Aynı zamanda, bu kuruluşların bağış yoluyla faaliyetlerini sürdürmesi, arza olan talepteki istikrarsızlık ve öngörülemeyen talep tahminlerinden dolayı insanlara yeteri kadar gıdanın sağlanamaması gibi zorlukları da beraberinde getirmektedir (Irwin, Ng, Rush, Nguyen ve He, 2007, s. 17).

Literatürde gıda bankacılığı ile ilgili çalışmalarda, genellikle gıda bankalarının yoksulluk üzerindeki etkileri ve finansal bakımdan şirketlere sağladığı avantajlar irdelenmiştir. Bu çalışma ise gıda bankalarının gıda kayıp ve israfına yönelik rolünü içermesi bakımından özgünlük taşımaktadır. Bu kapsamda, makalede gıda kayıp ve israfların nedenleri, kayıpların yaşandığı gıda grupları, meydana getirdiği ekonomik kayıplar, gıda bankacılığının kapsamı, sağladığı avantajlar, karşılaşılan zorluklar ve bunlara yönelik öneriler hakkında bilgiler verilmiştir.

\section{GIDA KAYIP VE İSRAFLARIN NEDENLERI}

Küresel gıda tedarik zinciri, nüfus ve çevresel baskıların bir sonucu olarak önemli zorluklarla karşı karşıyadır. Küresel nüfusun 2050 yılına kadar 2-3 milyar artacağı tahmin edildiğinde, gıda arzının da tahmini olarak \%77 artması gerekecektir. Kuraklık, seller ve iklim değişikliği gibi sebeplerle tarımsal alanların ve temiz suyun azalması da zorlukları artıran diğer sebepler olacaktır (Verghese, Lewis, Lockrey ve Williams, 2015, s. 603).

Tarımsal üretim alanlarının azalmasının yanında, tedarik zincirinde yaşanan kayıp ve israfların da giderek artması sürdürülebilir gıda teması ve çevre güvenliği için de tehlike oluşturmaktadır. Gıda ve Tarım Örgütü (FAO)'nün raporlarına göre gıda kayıplarının yaklaşık \%54'ünün üretim, hasat sonrası taşıma ve depolama sırasında meydana geldiği, \%46'sının ise işleme, dağıtım ve tüketim aşamalarında oluştuğu bildirilmektedir. Bu gıda kaybı ve israfın; yalnızca küresel gıda güvencesini iyileştirmek için kaçırılan bir fırsat değil, aynı zamanda çevresel kaynakların da gereksiz yere kullanılması ile ilgili de bir problem yarattı̆̆ı düşünülmektedir (Dhami, 2020, s. 38).

Gıda kaybı ve israfının nedenleri aşağıdaki gibi sınıflandırılabilmektedir (Reich ve Foley, 2014, s. 2);

-Arzın garanti altına alınması için mahsullerin fazla üretilmesi,

- Hasat yatırımlarının azalan getirisi nedeniyle mahsullerin hasat edilmemesi,

-Hasat, depolama, işleme ve dağıtımda meydana gelen aksaklıklar,

-Standardı sağlamayan ürünlerin israfına yol açan yüksek standartlar,

-Tüketicilerin kafasını karıştıran tarih etiketleri,

-Büyük porsiyon boyutları nedeniyle artan gıdaların yeniden tüketimindeki zorluklar,

- Gida kayıplarının oluşumu ve etkileri konusunda yetersiz bilinçlendirme (Reich ve Foley, 2014, s. 2). 
Üretici düzeyinde meydana gelen kayıpların başlıca nedeninin ise iki faktöre bağlı olduğu bildirilmiştir. Birincisi, alıcıların talep ettiği katı kalite standartlarının, yetiştiricileri ürünü hasat edilmeden bırakmaya zorladığını göstermektedir. İkincisi ise, satın alma fiyatlarının hasat maliyetini karşılamaya yetmediği zaman meydana gelen zararlardır (Johnson vd., 2019, s. 2). Mahsullerin fazla üretilmesi nedeniyle fiyatların gereğinden fazla düşmesi de, tüketicilerin daha fazla ürün almasına ve bu da israfın artmasına neden olmaktadır (Lintsen, Veraart, Smits ve Grin, 2018). Gelişmekte olan ülkelerdeki geleneksel depolama uygulamaları, temel gıda mahsullerini depo zararlılarına karşı korumayı garanti edememektedir. Ayrıca ürünler için uygun depolama yapılarının eksikliği, depolama yönetimi teknolojilerinin olmaması ve çeşitli mikroorganizmaların meydana getirdiği mikotoksinlerden kaynaklanan bozulmalar ürünlerde kayıpların oluşmasına neden olmaktadır (Tefera vd., 2011, s. 240). Bununla birlikte gıda kayıpları sadece üretim sırasında değil, hasat sonrası işleme ve dağıtımda da meydana gelmektedir (Kummu vd., 2012, s. 479). Ayrica gidalar; lojistik tesisler veya altyap1 yetersizliğinden ve dağıtım koşullarında uygun sıcaklık koşullarının sağlanamamasından kayba uğramaktadır (Raut, Gardas, Narwane ve Narkhede, 2019, s. 1). Öte yandan, meyve ve sebzelerin \%20-40'ı, tüketiciler ürünleri satın almadan genellikle görünüşleri beğenilmediğinden dolayı çöpe atılmaktadır. Bu israfın çoğu; meyve/sebzelerin şekli, boyutu, rengi, ağırlığı ve leke seviyesine ilişkin katı görünüş standartlarının takip edilmesinden kaynaklanmaktadır. Kusurlu "çirkin" meyve ve sebzeler besin değerini korumalarına rağmen, bunlar ya hasat edilmemekte ya da gida perakendecileri bu ürünü satmak istemedikleri için hasat ve satış arasında israf edilmektedir (Yuan, Yi, Williams ve Park, 2019, s. 2667). Gıda ambalajları üzerinde yer alan tarih etiketlerinin ("Son Kullanma Tarihi" ve "Tavsiye Edilen Son Tüketim Tarihi"), tüketicilerde kafa karışıklığı yaratmasından dolayı, gıdalar tüketim tarihleri sona ermeden önce çöpe atılmakta ve bu da gıda israfının artmasına neden olmaktadır. Ayrıca tüketiciler, gıda güvenirliliği nedeniyle tarih etiketinde belirtilen zaman yaklaştıkça gıda ürünlerini israf etmektedir (Wilson, Rickard, Saputo ve Ho, 2017, s. 36). Ortalama porsiyon ve paket boyutları zamanla arttığından dolayı, günümüz tüketicileri aldıkları yiyeceklerin daha büyük bir kısmını israf etmektedir (Krishna ve Hagen, 2019, s. 15). Bununla birlikte tüketicilerin, yemekten kalanları tekrardan yememesinin en büyük nedenleri arasında, tekrar aynı yiyecekleri tüketmeyi sevmeme veya genellikle taze gıdaları tüketme istekleri sayılabilmektedir (Urrutia, Dias ve Clapp, 2019, s. 5). Ayrıca tüketiciler gıda israfı konusunda düşük eğitim seviyesine sahip olup, kendilerinin yarattığı gıda atıklarının, ülkenin gıda israfına katkısına ilişkin bilgiye sahip değillerdir (Graham-Rowe, Jessop ve Sparks, 2014, s. 16).

Gıda tedarik zincirindeki meydana gelen kayıpların engellenmesinde ilk aşama üretici kısmında başlamaktadır. Bu kapsamda çiftçiler arasındaki iletişim ve iş birliğinin artırılması sağlanarak, fazla üretimin önüne geçilmesi gerekmektedir. Aynı zamanda, gıdalarda çok sıkı kalite standartları gerektirmeyen çiftlik marketleri yaygınlaştırılarak, yüksek kalite standartlarını sağlayamayan gıdalardaki kayıplar engellenmelidir (FAO, 2011, s. 10-11). Kayıpların meydana geldiği ikinci aşama ise dağıtım kısmıdır. Bu aşamada görülen en önemli sorun yetersiz ambalajlamadır. Bu amaçla ambalaj materyallerinin ve ambalaj tekniklerinin iyi seçilmesi, kayıpların azaltılmasında elzemdir (Verghese vd., 2015, s. 615-617). Tüketicilerin de "çirkin" gıdalara olan ön yargılarının önlenmesi gerekmektedir. Bu amaçla, süpermarketlerde tadım standları açılarak, önyargıyla olumsuz yaklaşılan "çirkin" gıdaların tatlarının, görünüşü iyi olan gidalarla karşılaştırıldığında farksız olduğu gösterilmelidir (De Hooge vd., 2017, s. 81). Perakendeciler, ödeme noktalarında otomatik fiyat indirimi yoluyla son kullanma tarihi 
yaklaşmış olan gıdalar için indirimler uygulamalıdır (Stuart, 2009, s. 202). Bu şekilde tüketicilerin "iki ürün fiyatına üç ürün gibi" israfa neden olan promosyonları tercih etmemesi sağlanmalıdır. Devletler, gıda ambalajları üzerinde yer alan "Son Kullanma Tarihi" ve "Tavsiye Edilen Son Tüketim Tarihi" kavramlarına ilişkin açıklamaları bilinçlendirme kampanyaları yoluyla gerçekleştirmelidir. İsrafın çokça yaşandığı, oteller ve restoranlar gibi hizmet yerlerinde açık büfe konsepti yerine ölçülü porsiyonlarla hizmet verilmelidir (Halloran, Clement, Kornum, Bucatariu ve Magid, 2014, s. 298-299). Bununla birlikte devletlerin, altyapı ve dağıtım için gerekli olan yollar konusunda da yatırımlar yapması gerekmektedir. Özel sektöründe soğuk depolar konusunda yatırımlarını artırması önem arz etmektedir (FAO, 2011, s. 11).

\section{KAYIPLARIN YAŞANDIĞI GIDA GRUPLARI}

Sınıflandırma, gıdaların içsel özellikleri, mevsimsel üretim miktarları, biyolojik varyasyona bağlı kalite süreçleri, gıda tedarik zincirinin her adımında gereken kalite özellikleri, gıda tipine bağlı olarak değişen nakliye ve depolama gereksinimleri ve kontrol kıstaslarına göre farklılıkların belirlenmesini sağlamaktır (Lemaire ve Limbourg, 2019, s. 1223).

Richter ve Bokelmann (2016, s. 428) tarafından yapılan çalışmada, ürün kusurları, son kullanım tarihi ve teknik hatalar bakımından en fazla kaybın et ve balık endüstrisinde olduğu ve kötü planlama, ticaret standartları ve perakende gereksinimleri yüzünden en fazla kaybın ise meyve ve sebze endüstrisinde yaşandiğı tespit edilmiştir. Diğer bir çalışmada da (Cicatiello, Franco, Pancino, Blasi ve Falasconi, 2017, s. 278-279) miktar olarak en fazla kaybın meyve ve sebzelerde meydana geldiği, bu ürün grubunu sırasıyla unlu mamüller ve süt ürünlerinin takip ettiği bulunmuştur. Meyve ve sebzelerde meydana gelen kayıpların en önemli nedeni çürümeler olup, unlu mamüllerdeki kayıplar ise tüketicilerin bu gibi ürünleri her zaman taze olarak bulmak istemelerinden kaynaklanmaktadır. Ayrıca unlu mamüllerin fiyatının da düşük olması kayıpları artırmaktadır. Priefer, Jörissen ve Bräutigam (2016, s. 156) tarafından gerçekleştirilen çalışmada da tüketici seviyesinde en fazla kaybın sırasılla meyve sebze, tahıl ve süt ürünlerinde görüldüğü, et ve balık ürünleri bakımından kayıpların ise nispeten küçük olduğu belirlenmiştir. Hayvansal kökenli diyetlere nazaran insanların tahıl tabanlı diyetlere yönelmesi, bu ürün grubunda kayıpların fazlalaşmasına neden olmaktadır. Fakat et ürünlerinde kayıp her ne kadar küçük olsa da, et ürünlerinin üretimi için çok fazla kaynak kullanımının gerekmesi ve yüksek sera gazına neden olması gözden kaçırılmaması gereken konulardandır.

Kayıpların önemli bir düzeyde gerçekleştiği diğer ürün grubu ise konaklama endüstrisinde yer alan yemeklerdir. Otelcilik sektöründeki israfın, toplam gıda israfına katkısının yaklaşık \%12 olduğu düşünüldüğünde, konaklama sektöründeki israfların hızla artması büyük bir endişe yaratmaktadır. Bunun en önemli sebebi, gelir ve turizmdeki büyümenin teşvik ettiği ev dışında yemek yeme eğilimidir (Dhir, Talwar, Kaur ve Malibari, 2020, s. 2). Avrupa Birliği genelinde konaklama sektörünün 12 milyon tonun üzerinde gıda israfına neden olduğu belirtilmiştir. Yalnızca İngiltere'de konaklama sektöründe yaklaşık 3 milyon ton gıda israf olmaktadır. İskandinav ülkelerinde ise bu değer yılda 0,45 milyon tonun üzerindedir (Filimonau ve De Coteau, 2019, s. 234).

Genel anlamda farklı gıda türlerinde bozulmayı hızlandıran etmenler bilinmeden, kayıpları engellemek mümkün değildir. Bu kapsamda süt ve süt ürünlerinde; depolama sıcaklığının yanlış seçimi, ortamdaki oksijen konsantrasyonu ve mikroorganizmalar raf ömrünü kısaltmaktadır (Lu ve Wang, 2017, s. 151). Et ve et ürünlerinde de mikrobiyal büyüme, 
oksidasyon ve enzimatik otoliz reaksiyonları etin bozulmasından sorumlu temel mekanizmalar olarak göze çarpmaktadır. Bununla birlikte, hayvanın kesim sırasındaki yaşı, kesim koşulları, işleme, dağıtım, muhafaza yöntemleri ve ambalajlama türü de etteki bozulma reaksiyonlarını etkileyen diğer faktörlerdir (Dave ve Ghaly, 2011, s. 486). Meyve ve sebzelerde, nem kaybı, zedelenmeler, enzimatik yumuşama ve mikrobiyal büyümeler raf ömrünü sinırlandırırken, ortam sıcaklığı, ışık, oksijen, nem ve taşıma koşulları da bu reaksiyonların hızlanması veya yavaşlanmasına etki etmektedir. Tahıllarda ise nişasta retrogradasyonu, nem kazanımı ve oksidasyon bozulmayı sağlamakta, bu bozulma reaksiyonlarını ortamdaki nem, sıcaklık, oksijen ve taşıma şekli etkilemektedir (Singh ve Anderson, 2004, s. 5). Konaklama sektöründe yaşanan gıda kayıplarının sebebi olarak, servis tabaklarının büyüklüğü, insanları yiyebileceklerinden fazlasını almaya teşvik eden sabit fiyatlarla açık büfe teklifleri, müşterinin ihtiyaçlarını karşılamayan ayrı porsiyon sunumlarının kullanılması, talebi değerlendirmedeki zorluklar (müşteri sayısı) ve çeşitli hijyen kuralları verilebilmektedir (Priefer vd., 2016, s. 157).

\section{GIDA KAYIP VE İSRAFLARININ EKONOMIK BOYUTU}

Gıda ürünlerinde yaşanan kayıp ve israflar ülke ekonomilerine büyük zarar vermektedir. Çünkü bir gıdanın üretiminden tüketiciye ulaşıncaya kadar geçirdiği tüm aşamaları bir bütün olarak değerlendirdiğimizde tarımsal arazilerin hazırlanmasında kullanılan kaynaklar (iş gücü, su, gübre, zirai ilaç, mazot v.b.), üretim ve tedarik zincirinde harcanan zaman (ürünün temin edilmesi, taşınması ve depolanması için gereken zaman) da israf edilen gıdayla birlikte boşa harcanmaktadır (Vilariño, Franco ve Quarrington, 2017, s. 3). Bu nedenle gida tedarik zincirindeki tüm paydaşlar; gıda kayıp ve israfının önlenmesi neticesinde meydana gelecek olumlu etkileri anladıklarında, bu sorunun önlenmesine katkı sağlayabileceklerdir (Ishangulyyev, Kim ve Lee, 2019, s. 5).

Ekonomik olarak, gıda kayıp ve israflarını azaltma girişimleri genellikle çiftçiler üzerinde olumsuz bir etkiye sahiptir. Çünkü bu tür girişimler gıda arzında artışa neden olabilir. Öte yandan, gıda kayıp ve israfında azalma, gıda işleyicilerinin daha düşük fiyatlarla daha fazla satış yapabilmesine olanak sağlarken, tüketicilerde ise gıdaların daha düşük fiyatlardan alınmasını sağlayarak tasarrufa neden olabilmektedir. Ayrıca, gelişmiş ülkelerde gıda kayıp ve israfını azaltma çabalarının, gelişmekte olan ülkelerdeki gıda fiyatlarını düşürebileceği, fakir insanları doyurmak için kullanılabilecek kaynakları kurtarabileceği ve tedarik zincirlerinde verimliliği artırabileceği düşünülmektedir (Abiad ve Meho, 2018, s. 312). Amerika Birleşik Devletleri'nde, perakende ve tüketici düzeyinde, gida kaybının toplam değerinin 165,5 milyar \$ civarında olduğu bildirilmiştir (Buzby ve Hyman, 2012, s. 561). Yeni Zelanda'da tüketim aşamasında oluşan gıda kayıplarının yıllık 872 milyon \$ olduğu (Reynolds, Mirosa ve Clothier, 2016, s. 2), Almanya'da perakende ve tüketici düzeyinde kişi başına 331 \$'lık zarar oluşturduğu tespit edilmiştir (Bräutigam, Jörissen ve Priefer, 2014, s. 684). Kanada'da ise gıda tedarik zincirinin tüm aşamaları hesaba katıldığında bu kaybın yıllık 26,6 milyar \$ olduğu bildirilmiştir (Gooch, Felfel ve Marenick, 2010, s. 15). Birleşik Krallık örneğinde ise, israf edilen toplam yiyecek ve içecek maliyetinin yaklaşık 15 milyar £/yıl olduğu belirlenmiştir (Quested ve Johnson, 2009, s. 28). Yapılan araştırmalarda Türkiye' de yıllık israf edilen gıdanın 26 milyon ton olduğu belirtilmekte olup, ekonomik karşılığının ise 214 milyar € olduğu düşünülmektedir (TGDF, 2020). Dünya'da ise gıda kayıp ve israflarının değerinin her yıl 940 milyar \$'ına karşılık geldiği bildirilmiştir (FAO, 2016). 
Bu sonuçlarla birlikte, yapılan araştırmalar gıda kaybı ve israfının sosyoekonomik etkilerini ayrıntılı olarak değerlendirmek için şu anda yeterli bilgi olmadığını da göstermektedir. Çünkü gıda kayıp ve israfıyla ilgili güvenilir ve tutarlı verilerin bulunması zor olduğundan, bölgeler ve ülkeler arasında karşılaştırma yapmak zorlaşmaktadır. Ayrıca bu kayıpları azaltmaya yönelik yatırımların çok maliyetli olacağı konusunda da tartışmalar vardır ve bu tartışmalar ne kadar "zarar"ın kabul edilebileceği sorusunu gündeme getirmektedir (Vilariño vd., 2017, s. 3-4).

\section{GIDA BANKACILIĞI}

Yoksulluk ve gıda israfı terimlerinin her ikisi de Birleşmiş Milletler tarafından önerilen "Sürdürülebilir Kalkınma Hedeflerine" dahil edildiğinden, devletler tarafından öncelikli alan olarak nitelendirilmektedir. Bu amaçla gıda israfını azaltmayı ve olumlu bir sosyal etki yaratmayı amaçlayan alternatif çözümler neticesinde, gıda bankaları öne çıkmaktadır (Michelini, Principato ve Iasevoli, 2018, s. 205-206). Yoksulluk terimi gıda açısından değerlendirildiğinde, insanların yeterli kalite ve miktarda besine ulaşamaması veya gıdayı elde etmede yaşadıkları belirsizlikler anlaşılmaktadır (Vatansever Deviren ve Kurtuluş, 2020, s. 981). Gıda güvencesizliği olarak da adlandırılan bu kavram; ekonomik ve politik riskler ve iklim değişiklikleri gibi çeşitli risk faktörlerinden etkilenmekte olup, FAO tarafından Dünya'da Gıda Güvenliği ve Beslenme Durumu raporu olarak yayınlanmaktadır (FAO, 2019, s. 5). Gıda güvencesinin izlenmesinde; bulunabilirlik, erişilebilirlik, kullanılabilirlik ve istikrar gibi ölçütler kullanılmakta ve bu ölçütlere bağlı olarak hesaplanan “Küresel Gıda Güvenliği Endeksinden” yararlanılmaktadır (Koç ve Uzmay, 2019, s. 239).

Gıda bankalarının temeli gıda yardımıyla ilişkili olup, gıda yardımı da yiyecek, kupon kullanımı veya nakit yardımı gibi yollarla gerçekleştirilebilmektedir. Yiyecek yardımı, gıdaların bağışı yoluyla gerçekleşirken, kupon seçeneği belirli mağazalarda belirli miktar veya değerdeki gıdaya erişimi kapsamaktadır. Nakit yardımı ise insanlara beslenme ihtiyacını karşılamak için verilen parayla ilgilidir. Bununla birlikte gıda yardımı resmi veya gayri resmi de olabilmektedir. Yardımı alma durumu, devlet ve ihtiyaç sahibi arasında oluşturulan sözleşmelerle şekillendiriliyorsa resmi, eğer sivil toplum kuruluşları ve diğer hayır kurumları tarafından yönetilmekte ve uygulanmaktaysa gayri resmi olarak adlandırılmaktadır (Gentilini, 2013, s. 78).

Gıda bankacılığı sistemi kavramsal olarak 1967 yılında John Van Hengel isminde emekli bir iş adamının Amerika Phoenix şehrindeki girişimleriyle başlamıştır. Hengel, gönüllü olarak çalıştığı aşevinin yıllık bütçesinin çok düşük olmasından dolayı bedava ürün bulmak için arayışlara girmiştir. Bu kapsamda tarımsal alanlarda çeşitli sebeplerle hasat edilmeyen sebze ve meyveleri toplamış ve aşevine getirmiştir. Fakat bu ürünlerin aşevi için gereğinden fazla olmasından dolayı, bunları diğer yardım kuruluşlarına teslim etmiştir. Daha sonra marketlerden fazla ürünleri toplamak amacıyla, eski bir fırını depo olarak kiralamış ve gıda bankasının ilk temellerini atmıştır (FEBA, 2020). 1976 yılında vergi reformunun uygulamaya konulmasıyla $\mathrm{ABD}^{\prime}$ de faaliyet gören diğer gıda bankaları da resmi bir kimliğe bürünmüş ve 1979'da “Amerika'nın İkinci Hasatı" ismiyle tek bir organizasyonda toplanmıştır. 2008 yılında ise ismi Feeding America (Amerika'yı Beslemek) olarak değiştirilmiş ve günümüzde de bu isimle faaliyetlerine devam etmektedir (Öğüz ve Akarçay, 2015, s. 3).

Avrupa'da ise ilk gıda bankası Paris'te 1984 yılında kurulmuştur. Daha sonra Fransa, İspanya ve İtalya tarafından 23 Eylül 1986'da kurulan Avrupa Gıda Bankaları Birliği (Sayın, 2013, s. 29), 
farklı tarihlerde çeşitli ülkelerinde katılımıyla 2019 itibariyle 430 gıda bankasını içerecek şekilde genişlemiştir (FEBA, 2019).

Gıda israfının azaltılması da, gıda yardımının yönetimine dair politikalara bağlı olup, bu amaçla gıda bankaları kullanılabilmektedir. Gıda bankaları üç yolla gıdayı tedarik etmektedir. Bunlardan birincisi bağışlar olup, bunlar aşırı sipariş nedeniyle meydana gelen stok fazlaları, iptal edilen siparişler, hava koşullarındaki değişiklikler, alıcı tercihlerinin değişmesi ve üretim hataları gibi çeşitli nedenlerden üreticiler, toptancılar ve perakendeciler tarafından sağlanan ürünlerdir. İkinci yol, doğrudan üreticilerden maliyet fiyatına gıdanın satın alınması iken üçüncü yol ise "İşbirlikçi Tedarik Programından" yararlanmaktır. Bu program vasıtasıyla gıda bankaları, diğer tedarikçiler veya üreticilerden bağış alarak, gerekli temel gıdaları (süt, kahvaltılık gevrekler, makarna) üretmek için üreticinin ihtiyaç duyduğu bazı bileşenleri sağlamaktadır (Booth ve Whelan, 2014, s. 1397).

Gıda bankalarındaki ürünler; çeşitli nedenlerle hasat edilmek istenmeyen gıdalardan elde edilebildiği gibi, endüstride gereğinden fazla üretilen gıdalardan da sağlanabilmektedir. Ayrıca marketlerde satılmayan gıdalar da gıda bankaları tarafından toplanabilmektedir. Fakat bu ürün kazanım stratejileri çeşitli zorluklar içerebilmektedir. Ĕger fazla üretim yapan tarla veya fabrikalar, gıda bankalarına uzaksa teslim aşaması bir artı maliyet oluşturmaktadır. Bağış̧̧ılar, gıdaların kalitesi konusunda emin olmadıklarından sağlık riskleri ve buna bağlı oluşabilecek yasal yaptırımlara karşı endişe duymaktadır (Lipinski vd., 2013, s. 12). Gıda bankalarının sınırlı bütçeleri ve kamudan gelen mali desteklerde çeşitli kesintiler yaşaması da zorluklara neden olmaktadır. Bu finansal kısıtlar; hem hizmet hem de "ürün" kalitesini iyileştirmek için "yatırım" yapma olanaklarını sınırlamaktadır. Özellikle gıdaların alıcılara sunulma şeklinin çeşitliliği, alıcılarda bazen öfke ve utanç duygularına neden olabilmektedir (Caraher, Cavicchi, Van der Horst, Pascucci ve Bol, 2014, s. 1517).

Dünyadaki örneklere bakıldığında; 'Feeding America' (FA) organizasyonunun 200 üye gıda bankası içerdiği, 40 milyon insana yardım ettiği ve 3,6 milyar ton gıdanın israfını önlediği belirlenmiştir (FA, 2019, s. 8-11). European Food Bank (FEBA), kuruluşunun da 2019 yılında 430 gıda bankasına sahip olduğu, 9,5 milyon insana yardım ettiği ve 768 bin ton gıdanın yeniden dağıtıma çıkarıldığı rapor edilmiştir (FEBA, 2019, s. 3). Global FoodBanking Network (GFN) organizasyonu ile 44 ülkeye ulaşıldığı, 919 milyon kg gıdanın dağıtıldığı ve 16,9 milyon ton gıdanın insanla buluşturulduğu saptanmıştır (GFN, 2020, s. 6). Hindistan'da Delhi Foodbanking Network (DFN) aracılığıyla, 20 milyon adet yemek, 17 bin çocuğa ulaştırılmıştır (DFN, 2020). Hindistan'da diğer bir organizasyon olan India Foodbanking Network (IFN) ise bünyesindeki 30 gıda bankası ve $25^{\prime}$ den fazla kurumsal ortağı ile günde yaklaşık 1 milyon adet yemeği ihtiyaç sahiplerine ulaştırmaktadır (IFN, 2020). Hong Kong'da ise "Feeding Hong Kong" organizasyonuyla 4,500 ton gida israftan kurtarılmış ve sonuç olarak 10 milyon adet yemek insanlara verilmiştir (FHK, 2020). Mısır'da "Egyptian Food Bank" farklı ülkelerde 27 gida bankasının kurulmasına yardımcı olmuş ve 2009-2012 yılında aylık olarak yaklaşık 15 milyon adet yemeği ihtiyaç sahiplerine ulaştırmıştır (EFB, 2020).

Sonuç olarak, gıda bankalarının ister gelişmiş ister gelişmemiş ekonomiye sahip tüm ülkelerde sayıca arttığı görülmektedir. Çünkü gıda bankaları; geçimlerini sağlaması için yeterli kaynakları olmayanlara değerli bir hizmet sunmakta, bağışta bulunan şirketlere kurumsal sorumluluk bakımından avantaj yaratmakta, bireysel bağışçılara ise başkalarını düşünmenin verdiği huzuru yaşatmaktadır. Fakat tüm bu avantajlarına karşılık, gıda bankaları çeşitli endişelere de neden 
olmaktadır. Çünkü gıda bankalarının mevcudiyetinin aslında ülkelerde uygulanan ekonomik politikaların başarısızlığını gösterdiğine dair görüşler de bulunmaktadır (Ronson ve Caraher, 2016, s. 79-82).

\section{TÜRKIYY'DE GIDA BANKACILIĞI}

Türkiye'de Gıda Bankacılığı faaliyeti ilk olarak, Türkiye İsrafı Önleme Vakfının katkılarıyla Diyarbakır' da 20 Ocak 2004 tarihinde başlamış ve 2000 metrekarelik alanda faaliyet göstermek üzere Diyarbakır Gıda Bankası kurulmuştur. İkinci gıda bankası Konya' da, üçüncü gıda bankası ise Gaziantep'te faaliyetlerine başlamıştır (Akgül, 2004, s. 14). Bu bankaları takiben daha sonra birçok dernek ve vakıf gıda bankacılığı yapmak için kurulmuş ve işlev görmeye başlamıştır (Eren, 2012, s. 234). İçişleri Bakanlığı tarafından verilen bilgide Dernekler Bilgi Sistemine göre 2015 yılında 126 derneğin Gida Bankacılığı faaliyetinde bulunduğu bildirilmiş olup, bu derneklerin 24.063.134,59 £ değerinde gida yardımı yaptığ tespit edilmiştir (TBMM, 2018, s. 34). Çuhadar (2017, s. 692) tarafından yapılan çalışmada 2016 Şubat itibariyle 22 vakfın bu faaliyette bulunduğu belirtilmiştir.

Türkiye'de özellikle Temel İhtiyaç Derneği (TIDER) gıda bankacılı̆̆ı konusunda diğer sivil toplum kurulularına yol gösteren bir kuruluş olarak görülmekte olup, faaliyetlerine 2010 yılında Gıda Bankacılığı Derneği adıyla başlamıştır (TBMM, 2018, s. 44). TIDER ayrıca 'The Global FoodBanking Network' organizasyonunun sertifikalı ve Türkiye'deki tek üyesidir. Bugüne kadar 626,280 kişi TIDER ağına kayıtlı gıda bankalarından faydalanmış olup, 4,402 ton gıda yardımı yapılmıştır. Destek market kapsamında çalışan organizasyon, ihtiyaç sahiplerini bölge kaymakamlıklarına yapılan başvuru sonucu belirlemektedir. Belirlenen kişiler telefonlarına gelen alışveriş limitini SMS aracılığıyla öğrendikten sonra, destek markette alışverişlerini yapmaktadırlar. Ödeme işlemi kasada para ile olmayıp, ihtiyaç sahiplerinin kendilerine gelen mesajı göstererek, alışveriş tutarının kendilerine tanınan limitten düşmesiyle gerçekleşmektedir. TIDER'in diğer bir farkı ise insanlara istihdam bakımından da yardım etmesidir (TIDER, 2020). Bununla birlikte TIDER, OXIVO grup ve Kadıköy Belediyesi, COVID-19 salgını nedeniyle insansız gıda bankacılığı kapsamında, "Otomat Gıda Bankası" konseptini oluşturmuş ve 12 Ağustos 2020 tarihinde açlış gerçekleştirilmiştir. Otomatların kapasitesi 20 dolapla sınırlı olup, bu dolaplarda gıda ve temizlik ürünlerini içeren ve bir ailenin bir aylık ihtiyacını karşılayabilecek iki farklı koli çeşidi bulunmaktadır. Gıda kolileri; un, yağ, bakliyat, salça ve tuz gibi ürünleri içermekte olup, koliler dışında çeşitli gıda ve temizlik maddelerini tekil olarak içeren bölümde yer almaktadır. Kadıköy Belediyesi tarafından tespit edilen ihtiyaç sahipleri, telefonlarına gelen SMS kodunu, otomatta yer alan panele girmek suretiyle istediği kolilere ulaşabilmektedir (Süzer, 2020).

Dikkat çeken diğer bir organizasyon ise, dünyada en başarılı 5. program seçilen "Fazla Gıda Platformu"dur. Bu platform, dernek ve vakıfları marketlerle buluşturarak hizmet vermektedir. Bu sisteme göre; marketler platforma bağışta bulunacağı ürününü ve bu ürünün ne zamana kadar teslim alınabileceğini girmektedir. Daha sonra verilen bu ilana uygun olan dernek ve vakıflara bildirim gitmekte ve bu kuruluşlar ilana başvurarak eşleştirme gerçekleşmektedir. Bu işlemi takiben lojistik faaliyet gerçekleştirilmekte, en son olarak ise muhasebe ve kalite kontrol işlemleri gerçekleştirilerek süreç tamamlanmaktadır. Platform, 7 aylık süreç içerisinde gıda bankası hizmeti veren 42 derneğe ulaşmış ve 122 ton gida ürününü, 14,000 kişiye ulaştırmıştır (Silahlı, 2020). 
Manisa Büyükşehir Belediyesi 2016 yılı itibariyle Manisa'nın 17 ilçesinde gıda bankası kurmuş olup, 2014-2016 yılları arasında 21,727 aile bu hizmetten faydalanmıştır. Ayrıca gıda bankasından yararlanmak için başvuran kişi sayısının 12,058 olduğu belirtilmiş olup, kriterlere uygun olan 7,412 kişinin gıda bankalarından düzenli olarak istifade ettiği bildirilmiştir (Manisa, 2020). Gaziantep Büyükşehir Belediyesi de bireysel başvuru veya muhtarlar vasıtasılyla mahalle taraması ile belirlenen 11,568 aileye ulaşmış olup, gıda bankası vasıtasıyla bunlardan 4,069 aileye gida yardımı yapmıştır (Gaziantep, 2020). Çorum Belediyesi Gıda Bankası ise, salgın öncesi 8,000 aileye hizmet verirken, salgın sonrası ise 10,000 civarında aileye hizmet vermektedir (Çorum, 2020). Sakarya' da sosyal market kapsamında hizmet veren Gida Bankacılığı Derneği ise 2020 Şubat ayından itibaren 85 ton erzak ve 8,500 aileye temel ihtiyaç yardımı yapmıştır (GBD, 2020). Boğaziçi Vakfı Gıda Bankası ise 2008 yılında İstanbul'da kurulmuş olup, bu bankadan 2010-2012 yılları arasında yaklaşık 1,200 kişi yararlanmıştır. Yapılan yardımın gıda bakımından değeri 1,2 milyon £’dir. Çorum Alaca Gıda Bankasının ise 2011-2012 yılları arasında yaptığı gıda yardımlarının değeri 475,000 € civarındadır (Sayın, 2013).

Gıda Bankacılığı konusunda Türkiye'de yasal düzenlemeler ilk olarak 5035 sayılı Kanunla yapılmıştır. Bu düzenlemeyle birlikte Gıda Bankacılığı kapsamında Gelir ve Katma Değer Vergisi Kanununda değişiklik yapılarak, gıda bağışları gelir vergisi bakımından indirime konu olmuş ve KDV istisnası getirilmiştir. Gıda bankacılığı kapsamında yapılacak olan bağış, bağışa konu dernek ve vakıflar ile uygulanması gereken usul ve esaslara dair düzenlemeler ise Maliye Bakanlığı tarafından 21 Mart 2004 tarihli tebliğle açıklanmıştır (Kala, 2020, s. 195-196). Gıda Bankacılığının tanımının yapıldığı ve gıda bankalarının da gıda işletmecisi statüsünde değerlendirildiği 5179 sayılı “Gıdaların Üretimi, Tüketimi ve Denetlenmesine Dair Kanun Hükmünde Kararnamenin Değiştirilerek Kabulü Hakkında Kanun” ise 27 Mayıs 2004 tarihinde çıkartılmıştır (Çuhadar, 2017, s. 693). Gıda Bankacılığının gıda maddeleriyle birlikte, giyecek ve yakacak maddelerini de kapsayacak şekilde genişletildiği Gelir ve Katma Değer Vergisi Kanunu 5281 sayısıyla yürürlüğe girmiştir (Özden, 2019, s. 133). Belediyelerin de gida bankacılığ yapmasına olanak sağlayan 5393 sayılı Belediye Kanunu ise 3 Temmuz 2005 tarihinde kabul edilmiştir (Çuhadar, 2017, s. 691). 5996 sayılı “Veteriner Hizmetleri, Bitki Sağlı̆̆ı, Gıda ve Yem Kanunu"nun 13 Haziran 2010 tarihinde yayımlanmasıyla gida bankacılığının tanımının yapıldığı 5179 sayılı Kanun yürürlükten kaldırılmıştır. Günümüzde ise, gıda bankacılığıyla ilişkili uygulamalar 5281 nolu Kanuna göre yürütülmektedir (Kala, 2020, s. 196).

\section{GIDA BANKACILIĞININ SAĞLADIĞI AVANTAJLAR}

Gıda bankacılığı sistemi, işletme sahiplerine, tüketicilere ve devlete birtakım avantajlar sağlamaktadır. Bu kapsamda perakendeciler, gıda bankalarını bertaraf yeri olarak kullanarak fazla gıda stoklarının meydana getirdiği maliyetlerin önemli kısmını telafi etmektedir. Bu amaçla finanse edilen gıda geri kazanım programları, yalnızca israf sorunlarına sıfır maliyetli bir çözüm sunmamakta olup, aynı zamanda çok fazla gıda üretilmesiyle ilişkili finansal riskleri azaltmanın da karlı bir yoludur. Çünkü firmalar satılamayan envanterleri elden çıkarmak için para ödememekte, bunları gıda bankalarına vererek maliyetlerden kısmaktadır. Ayrıca, firmalar yaptıkları bu bağışları pazarlama aracı olarak da kullanarak kurumsal imajlarına katkı sağlamakta ve aynı zamanda fiyatların raflarda yüksek seyirde kalmasına yardımcı olmaktadır (Lohnes ve Wilson, 2018, s. 363). Bununla birlikte firmalar bankalar sayesinde piyasa dengesinin de korunmasını sağlamaktadır. Çünkü firmalar ellerinde bulunan fazla ürünleri düşük fiyattan 
sattığında piyasa istikrarı bozulmakta ve fiyat dengesi ortadan kalkmaktadır (Akartepe, 2016, s. 2).

Şirketler ayrıca gıda bankalarına yaptığı bağışlar nedeniyle vergi avantajı da elde etmektedir. Şöyle ki, gıda bankacılığı konusunda faaliyet yürütmeyen, fakat kamu yararı gözeten dernek ve vakıflara makbuz karşılığında yapılan bağışlarda, indirim tutarı elde edilecek gelirin \%5'i (kalkınmada öncelikli yerlerde ise \%10) kadardır (Eren, 2012, s. 239). Eğer şirketler yardım veya bağış işlemini makbuz almaksızın gıda bankacılığı faaliyeti göstermeyen derneklere yapar ise, bu durum kanunen kabul edilmeyen gider olarak görüleceğinden ve dönem ticari karına ekleneceğinden sanki kar elde etmiş gibi görünecektir (Akartepe, 2016, s. 5). Fakat bu yapilan yardım ve bağışlar gıda bankacılığı kapsamında yapıldığında ise, oran kısıtlaması olmamakta ve maliyetin tamamı gider olarak kaydedilerek, hesaplanacak yıllık gelirden düşülebilmektedir. Ayrıca bu bağışlar KDV'den de muaftır (Kala, 2020, s. 198).

Bedelsiz olarak yardım sağlayan gıda bankaları, ihtiyaç sahibi tüketiciler açısından ise kısa vadeli olarak gıda ihtiyacını gidermesi açısından avantaj sağlamaktadır. Özellikle zor zamanlarda alınan bu yardımlar, tüketicilerin rahat nefes almasına yardımcı olmaktadır (Çankaya, 2006, s. 162). Gıda bankalarının meydana getirdiği diğer bir avantaj ise dini açıdan zekat yükümlülüğünü gidermek amacıyla kişilerin bu kurumları kullanmasıdır (Akartepe, 2016, s. 7-8).

Devletler ise, mali kaynak yetersizliğinden dolayı kamu yararı kapsamında gerçekleştiremediği faaliyetleri gıda bankaları aracılığıyla gerçekleştirebilmektedir. Bu kapsamda, gıda bankaları ülkedeki açlık ve yoksulluk düzeyini azaltarak, sosyal adaletin sağlanmasına katkıda bulunmaktadır (Özden, 2019, s. 128-129). Ayrıca gıda bankaları çeşitli sebeplerle ellerinde fazla ürün bulunduran işletmelerden bu ürünleri toplayarak ülkede meydana gelen büyük miktardaki israfın önüne geçilebilmesinde devlete yardımcı olmaktadır (Akartepe, 2016, s. 1).

Gıda Bankacılığı konusunda diğer ülkeler verilen teşvikler açısından değerlendirildiğinde; İngiltere' de KDV ve mali destek bakımından ayrıcalık bulunmamaktadır. Fransa ve İtalya'da KDV alınmamakta ve bağış yapan şirketler belirli oranlarda vergi indiriminden yararlanmaktadır. Belçika'da ise Gıda Bankaları Federasyonu'na kayıtlı olmak koşuluyla şirketlerden KDV alınmamakta fakat vergi indirimi uygulanmamaktadır (TBMM, 2018, s. 30). İspanya'da KDV bakımından ayrıcalık bulunmamakta olup, bağış yapan şirketler bağışladığı ürünlerin net değerinin beli bir oranını kurumlar vergisinden mahsup edebilmektedir. Yunanistan, Macaristan, Polonya ve Portekiz'de KDV uygulanmamaktadır. İsveç'te ise gıda bağışlarında KDV uygulanmaktadır (TBMM, 2018, s. 57-58).

\section{GIDA BANKACILIĞINDA KARŞILAŞILAN ZORLUKLAR}

Gıda bankaları; gıda güvencesi, israf ve yoksulluğu azaltma konusunda sağladığı katkılar dışında, bazı zorlukları da içermektedir. Öncelikle gıda bağışının ön görülemeyen doğası nedeniyle, tüketicilerin ihtiyaçlarını karşılamak zor olmaktadır. Bu nedenle talep arzı geçtiğinden dolayı, tüketicilere sunulan gıdalar beslenme ihtiyaçlarını karşılamada yetersiz bulunmaktadır (Irwin vd., 2007, s. 17). Bu gibi durumlarda daha fazla müşteriye ulaşmak için, gıda seçimini sınırlama, verilen yiyecek miktarını azaltma ve talepleri reddetme olasılıkları da meydana gelmektedir (Tarasuk vd., 2014, s. 6). Bazı durumlarda ise gıda bankasına bağışlanan gıdaların kalitesi düşük olmakta veya gıda güvenliği açısından sıkıntılı ürünler içerdiğinden tüketiciler bunları tüketememektedir (Teron ve Tarasuk, 1999, s. 383). Ayrıca tüketicilerin 
aşağılanma korkusu nedeniyle, gıda bankası desteğine başvurmayı gerçekten çaresiz olana kadar erteleme durumları söz konusudur (Caraher vd., 2014, s. 1509). Bununla birlikte ihtiyaç sahiplerinin sübjektif kriterlere göre seçildiği ve bu nedenle gerçek ihtiyaç sahiplerine ulaşılamadığ

Ayrıca gıda bankalarının dağıtımını sağladıkları kolilerde, besinsel kaliteye ilişkin düzenlemelere sahip olmaması da sorun oluşturmaktadır (Handforth, Hennink ve Schwartz, 2013, s. 414). Gida bankaları tarafından yapılan yardım gida kolisi şeklinde ise genellikle meyve, sebze, et ve süt ürünlerini az içerdiğinden besinsel değerlerinin düşük olduğu da tespit edilmiştir. Bu ürünlerin gıda kolilerinde çok fazla yer almamasının nedeni ise bu gıdaların doğaları gereği depolanmalarının zor olması veya diğer gıdalara oranla daha az bağış yapılmasıdır (Irwin vd., 2007, s. 19). Bazı durumlarda şekerli içecekler ve atıştırmalık gıdaların bu tür dağıtımlarda büyük oranda yer alması ve bunların yüksek kalori içermesi nedeniyle, bu tür gıdaları tüketen ihtiyaç sahiplerinde obezite, diyabet ve kalp hastalığı riski de artmaktadır (Ross, Campbell ve Webb, 2013, s. 305-306).

Eğer gıda bankaları ihtiyaç sahiplerine araçlarla hizmet veriyorsa kolay bozulabilir gıdalar zaman kısıtlamalarına neden olmakta ve bu nedenle uzak noktalardaki ihtiyaç sahiplerine ulaşmada problem yaşanmaktadır. Bununla birlikte buralara araç göndermek için planlamada zorluklarla da karşılaşılmaktadır (Davis, Sengul, Ivy, Brock ve Miles, 2014, s. 175-176). Gıda bankacılığının, insanların ihtiyaçlarını, onları üretime katmadan karşılaması nedeniyle sürekliliğe yol açabileceği ve çalışabilecek durumda olan insanların çalışma isteğini azaltarak tembelliğe sürükleyeceği de düşünülmektedir (Özden, 2019, s. 129).

Gıda bankalarının karşılaştığı en önemli zorluk ise, gıda bankalarının devamlılığını sağlamak için yeterli para olmaması veya bu hizmetlerin gerçekleştirilebileceği tesislerin yetersizliğidir (Wie ve Giebler, 2013, s. 83). Ayrıca yapılan gıda yardımları, kişilere nakit para yardımını içermediğinden, insanların gıda dışı ihtiyaçlarını karşılayamamalarına neden olmaktadır. Bununla birlikte gıda bankaları, yoksulluk ve açlık konusunda devletlerin sorumluluğunu özel sektöre yüklemesi bakımından da problem olarak görülmektedir (Caraher ve Furey, 2017, s. 11).

\section{GIDA BANKACILIĞI SISTEMINIIN ETKINNLIGĞİNIN ARTIRILMASINA YÖNELIIK ÖNERILER}

Türkiye' de faaliyet gösteren gıda bankalarının daha iyi biçimde işlev görmesi için TBMM (2018, s. 119-125) tutanaklarına göre yapılması gerekenler şu şekilde belirlenmiştir;

-İhtiyaç sahibi ailelerin belirlenmesi ve mükerrer yardımların önlenmesi amacıyla, gıda bankacılığı faaliyetinde bulunan dernek ve vakıfların hem birbirleriyle hem de Aile ve Sosyal Politikalar Bakanlığıyla iş birliğine girmesi gerekmektedir.

- Gıda bankalarının çalışma standartlarının oluşturulması ve gıda güvenliğinin sağlanması amacıyla nakliye ve depolama bakımından teknik kapasitenin artırılması ve nitelikli eleman çalıştırılması önem arz etmektedir.

•Özel sektörün gıda bağışı konusunda teşvik ettirilmesi ve bu durumun düzenli olması sağlanmalıdır. Şirketlerin bağış sırasında yaşadığı sıkıntıların ve çekincelerin azaltılması gerekmektedir.

- Tüm şirketlerin gida bankacılığı konusunda bilgilendirilmesi ve şirketlere sağladığ avantajların çeşitli yollarla (reklam, çalıştay, broşür, kamu spotu) duyurulması lazımdır. 
- Gıda bankalarında sunulan ürünlerde meydana gelebilecek problemlerden, bağışlayan şirketlerin sorumlu tutulmayacağına dair ifadeler, şirketlerin imajlarını korumasına katkı sağlayabilecektir.

- Gıda tedarik zincirinin çeşitli aşamasında meydana gelen kayıların azaltılması amaciyla üreticiler, işleyiciler, nakliyeciler, perakendeciler ve devlet kurumlarının bilgilendirilerek, atıl durumda olan gıdaların gıda bankalarına yönlendirilmesi önem arz etmektedir.

- Gıda bankacılığı yapan dernek ve vakıfların zehirlenme riskini fazla gördüklerinden dolayı olumlu bakmadıkları artan sıcak yemeklerin, gıda bankalarına ulaştırılması için devlet ve özel şirketlerin soğuk zincir konusunda bu kuruluşları desteklemesi gerekmektedir. Bununla birlikte özellikle artan yemek miktarının fazla olduğu otel bölgelerinde yemekhanelerin kurularak, soğuk zincire gerek kalmadan israfın azaltılabileceği düşünülmektedir (TBMM, 2018, s. 119125).

\section{SONUÇ}

Son yıllarda pazarın küreselleşmesi ve tüketicilerin beklentilerinin artması gibi nedenler gıda tedarik zincirini hem uzatmakta hem de daha karmaşık bir hal almasını sağlamaktadır. Üretici ve tüketici arasında geçen bu sürenin artması, gıda kayıplarının da çeşitli sebeplerden dolayı daha fazla artmasına neden olmaktadır. Tüketici aşamasında gerçekleşen ve gıda israfı olarak adlandırılan kayıplar ise sosyal ve ekonomik değişimlerin bir sonucu olup, çöpe giden gıdanın üretilmesi için gereken su, enerji, toprak, emek ve sermaye girdilerinin de boşa gitmesi demektir. Bu kapsamda, gıda israf ve kayıplarının azaltılmasında bir çözüm yolu olarak görünen gıda bankaları, insan tüketimi için uygun olduğu halde çeşitli sebeplerle atılması düşünülen gıdaların çeşitli vakıf ve dernekler vasıtasıyla ihtiyaç sahiplerine ulaştırılmasını amaçlamaktadır. Bu bankalar, sadece ihtiyaç sahiplerine yardım etmeyip aynı zamanda şirketlere de sosyal sorumluluk ve vergi avantajı yönünden fayda sağlamaktadır. Ülkedeki yoksulluğu önleme ve sosyal adaleti yerine getirme bakımından da devletlere yararı bulunmaktadır. Fakat tüm bu avantajlarının yanında, gerekli bağışların yapılmaması nedeniyle talebin karşılanmaması gibi çeşitli zorlukları da içermekte olup, bu ve benzeri sorunların çözülmesiyle daha etkin bir düzeye ulaşabilecektir.

\section{KAYNAKÇA}

Abdulla, M., Martin, R., Gooch, M. ve Jovel, E. (2013). The importance of quantifying food waste in Canada. Journal of Agriculture, Food Systems and Community Development, 3(2), 137151.

Abiad, M. G. ve Meho, L. I. (2018). Food loss and food waste research in the Arab world: A systematic review. Food Security, 10(2), 311-322.

Akartepe, B. B. (2016). Türkiye'de gıda bankacıllğı ve zekat ile ilişkisi. İlemblog, 4, 1-11.

Akgül, A. (2004). Açlığın önlenmesinde g1da bankacıllı̆ı. Türkiye İsrafı Önleme Vakfı, 1-40. 
Bazerghi, C., McKay, F. H. ve Dunn, M. (2016). The role of food banks in addressing food insecurity: A systematic review. Journal of Community Health, 41(4), 732-740.

Booth, S. ve Whelan, J. (2014). Hungry for change: The food banking industry in Australia. British Food Journal, 116(9), 1392-1404.

Bräutigam, K. R., Jörissen, J. ve Priefer, C. (2014). The extent of food waste generation across EU27: Different calculation methods and the reliability of their results. Waste Management E Research, 32(8), 683-694.

Buzby, J. C. ve Hyman, J. (2012). Total and per capita value of food loss in the United States. Food Policy, 37(5), 561-570.

Caraher, M., Cavicchi, A., Van der Horst, H., Pascucci, S. ve Bol, W. (2014). The "dark side" of food banks? Exploring emotional responses of food bank receivers in the Netherlands. British Food Journal, 116(9), 1506-1520.

Caraher, M. ve Furey, S. (2017). Is it appropriate to use surplus food to feed people in hunger? Short-term band-aid to more deep rooted problems of poverty. Food Research Collaboration, 1-22.

Cicatiello, C., Franco, S., Pancino, B., Blasi, E. ve Falasconi, L. (2017). The dark side of retail food waste: Evidences from in-store data. Resources, Conservation and Recycling, 125, 273-281.

Çankaya, F. (2006). Yoksulluğun giderilmesinde yeni arayışlar: Gıda bankacılı̆̆ı ve muhasebe işlemleri. Süleyman Demirel Üniversitesi İktisadi ve İdari Bilimler Fakültesi Dergisi, 11(1), 155-172.

Çorum. (2020). Paranın geçmediği gıda bankası ihtiyaç sahiplerinin yüzünü güldürüyor. 2 Ocak 2021 tarihinde https://www.iletisim.gov.tr/turkce/yerel_basin/detay/paranin-gecmedigigida-bankasi-ihtiyac-sahiplerinin-yuzunu-gulduruyor adresinden erişildi.

Çuhadar, S. G. (2017). Sosyal politika ile klientalizm ilişkisi; gıda bankacılığı üzerinden bir değerlendirme. Calisma ve Toplum, 53(2), 681-703.

Dave, D. ve Ghaly, A. E. (2011). Meat spoilage mechanisms and preservation techniques: A critical review. American Journal of Agricultural and Biological Sciences, 6(4), 486-510.

Davis, L. B., Sengul, I., Ivy, J. S., Brock, L. G. ve Miles, L. (2014). Scheduling food bank collections and deliveries to ensure food safety and improve access. Socio-Economic Planning Sciences, 48(3), 175-188.

De Gorter, H., Drabik, D., Just, D. R., Reynolds, C. ve Sethi, G. (2020). Analyzing the economics of food loss and waste reductions in a food supply chain. Food Policy, 101953.

De Hooge, I. E., Oostindjer, M., Aschemann-Witzel, J., Normann, A., Loose, S. M. ve Almli, V. L. (2017). This apple is too ugly for me!: Consumer preferences for suboptimal food products in the supermarket and at home. Food Quality and Preference, 56, 80-92.

DFN. (2020). Delhi Food Banking. What we do - serving to create a better future for Children Across India. 2 Ocak 2021 tarihinde https://www.delhifoodbanking.org/about-foodbank-indiafood-charity-for-children/ adresinden erişildi. 
Dhami, K. S. (2020). Postharvest loss reduction for sustainable food and environmental security. Food and Scientific Reports, 1, 38-40.

Dhir, A., Talwar, S., Kaur, P. ve Malibari, A. (2020). Food waste in hospitality and food services: A systematic literature review and framework development approach. Journal of Cleaner Production, 270, 122861.

EFB. (2020). Egyptian Food Bank. Our experience and achivements. 2 Ocak 2021 tarihinde https://www.egyptianfoodbank.com/en adresinden erişildi.

Eren, M. (2012). Fakirlere yardım etmek maksadıyla kurulan gıda bankacılığının vergisel boyutu ve muhasebeleştirilmesi. Mali Çözüm, Temmuz A ğustos, 229-252.

FA. (2019). Feeding America. 2019 Annual report. 3 Kasım 2020 tarihinde https://www.feedingamerica.org/sites/default/files/2020-

06/FA_2019_AnnReport_d8.pdf adresinden erişildi.

FAO. (2011). Food and Agriculture Organization. Global food losses and food waste - extent, causes and prevention. 3 Ekim 2020 tarihinde http://www.fao.org/3/a-i2697e.pdf adresinden erişildi.

FAO. (2016). Food and Agriculture Organization. Food waste: A global challenge, a local solution. 1 Eylül $\quad 2020 \quad$ tarihinde http://www.fao.org/cfs/home/blog/blogarticles/article/en/c/449010/ adresinden erişildi.

FAO. (2019). Food and Agriculture Organization. Dünyada gıda güvenliği ve beslenme durumu - 2019. 5 Eylül 2020 tarihinde http://www.fao.org/3/ca5249tr/ca5249tr.pdf adresinden erişildi.

FEBA. (2019). European Food Banks Federation. Annual report 2019. 9 Eylül 2020 tarihinde https://lp.eurofoodbank.org/wpcontent/uploads/2020/06/FEBA_2019_Annual_Report_FINAL.pdf adresinden erişildi.

FEBA. (2020). European Food Banks Federation. Our mission. 16 Aralı 2020 tarihinde https://www.eurofoodbank.org/en/mission-vision-values adresinden erişildi.

FHK. (2020). Feeding Hong Kong. Our impact since 2011. 2 Ocak 2021 tarihinde https://feedinghk.org/ adresinden erişildi.

Filimonau, V. ve De Coteau, D. A. (2019). Food waste management in hospitality operations: A critical review. Tourism Management, 71, 234-245.

Gaziantep. (2020). Gaziantep Büyükşehir Belediyesi. Gıda bankası bir yılda 11 bin kişiye ulaştı. 2 Ocak 2021 tarihinde https://www.gaziantep.bel.tr/tr/haberler/gida-bankasi-bir-yilda-11-binkisiye-ulasti adresinden erişildi.

GBD. (2020). Gıda Bankacıllı̆ı Derneği. Sosyal market uygulamamız. 2 Ocak 2021 tarihinde https://www.gidabankaciligi.com.tr/gida-bankaciligi-sosyal-market-uygulamamiz/ adresinden erişildi.

Gentilini, U. (2013). Banking on food: The state of food banks in high-income countries. IDS Working Papers, 2013(415), 1-18. 
GFN. (2020). The Global FoodBanking Network. 2020 Annual report. 17 Aralık 2020 tarihinde https://www.foodbanking.org/wp-content/uploads/2020/12/GFN-2020-AnnualReport.pdf adresinden erişildi.

Gooch, M., Felfel, A. ve Marenick, N. (2010). Food waste in Canada: Opportunities to increase the competitiveness of Canada's agri-food sector, while simultaneously improving the environment. Value Chain Management Centre, November, 1-16.

Graham-Rowe, E., Jessop, D. C. ve Sparks, P. (2014). Identifying motivations and barriers to minimising household food waste. Resources, Conservation and Recycling, 84, 15-23.

Halloran, A., Clement, J., Kornum, N., Bucatariu, C. ve Magid, J. (2014). Addressing food waste reduction in Denmark. Food Policy, 49, 294-301.

Handforth, B., Hennink, M. ve Schwartz, M. B. (2013). A qualitative study of nutrition-based initiatives at selected food banks in the feeding America network. Journal of the Academy of Nutrition and Dietetics, 113(3), 411-415.

IFN. (2020). India Food Banking. Our network. 2 Ocak 2021 tarihinde https://www.indiafoodbanking.org/about/network adresinden erişildi.

Irwin, J. D., Ng, V. K., Rush, T. J., Nguyen, C. ve He, M. (2007). Can food banks sustain nutrient requirements? Canadian Journal of Public Health, 98(1), 17-20.

Ishangulyyev, R., Kim, S. ve Lee, S. H. (2019). Understanding food loss and waste-Why are we losing and wasting food? Foods, 8(8), 297.

Johnson, L. K., Bloom, J. D., Dunning, R. D., Gunter, C. C., Boyette, M. D. ve Creamer, N. G. (2019). Farmer harvest decisions and vegetable loss in primary production. Agricultural Systems, 176, 102672.

Kala, E. S. (2020). Türkiye'de gıda bankacılığı mevzuatı ve uygulamaları. Yönetim ve Ekonomi Araştırmaları Dergisi, 18(3), 190-211.

Koç, G. ve Uzmay, A. (2019). Küresel gıda güvencesinin izlenmesi ve haritalanması üzerine bir değerlendirme. Adnan Menderes Üniversitesi Ziraat Fakültesi Dergisi, 16(2), 237-244.

Krishna, A. ve Hagen, L. (2019). Out of proportion? The role of leftovers in eating-related affect and behavior. Journal of Experimental Social Psychology, 81, 15-26.

Kummu, M., De Moel, H., Porkka, M., Siebert, S., Varis, O. ve Ward, P. J. (2012). Lost food, wasted resources: Global food supply chain losses and their impacts on freshwater, cropland, and fertiliser use. Science of The Total Environment, 438, 477-489.

Lemaire, A. ve Limbourg, S. (2019). How can food loss and waste management achieve sustainable development goals? Journal of Cleaner Production, 234, 1221-1234.

Lintsen, H., Veraart, F., Smits, J. P. ve Grin, J. (2018). Well-being, Sustainability and Social Development: The Netherlands 1850-2050. London: Springer Nature.

Lipinski, B., Hanson, C., Lomax, J., Kitinoja, L., Waite, R. ve Searchinger, T. (2013). Reducing food loss and waste. World Resources Institute Working Paper, 1, 1-40.

Lohnes, J. ve Wilson, B. (2018). Bailing out the food banks? Hunger relief, food waste, and crisis in Central Appalachia. Environment and Planning A: Economy and Space, 50(2), 350-369. 
Lu, M. ve Wang, N. S. (2017). Spoilage of milk and dairy products. The microbiological quality of food 151-178. Amsterdam: Elsevier.

Manisa, B. (2020). Manisa Büyükşehir Belediyesi. Gıda bankaları. 2 Ocak 2021 tarihinde https://www.manisa.bel.tr/Projeler/d53_gida-bankalari.aspx adresinden erişildi.

Michelini, L., Principato, L. ve Iasevoli, G. (2018). Understanding food sharing models to tackle sustainability challenges. Ecological Economics, 145, 205-217.

Oral, Z. (2015). Dünya'da ve Türkiye'de gıda israfi ve önlenmesine yönelik uygulamalar. Yayınlanmamış AB uzmanlık tezi, T.C. Gıda Tarım Ve Hayvancılık Bakanlığı, Ankara.

Öğüz, A. A. ve Akarçay, Ç. (2015). Türkiye'de uygulanan gıda bankacılığı sisteminin işleyişi ve vergisel avantajlarının diğer ülkelerle karşılaştırılması. Öneri, 11(44), 1-16.

Özden, E. (2019). Vergi avantajları boyutuyla gıda bankacılığı sistemi. Mali Çözüm, 29, 123-143.

Priefer, C., Jörissen, J. ve Bräutigam, K. R. (2016). Food waste prevention in Europe-A causedriven approach to identify the most relevant leverage points for action. Resources, Conservation and Recycling, 109, 155-165.

Quested, T. ve Johnson, H. (2009). Household food and drink waste in the UK: Wastes \& Resources Action Programme (WRAP).

Raut, R. D., Gardas, B. B., Narwane, V. S. ve Narkhede, B. E. (2019). Improvement in the food losses in fruits and vegetable supply chain - a perspective of cold third-party logistics approach. Operations Research Perspectives, 6, 100117.

Reich, A. H. ve Foley, J. A. (2014). Food loss and waste in the US: The science behind the supply chain. University of Minnesota. Food Policy Research Center, 1-4.

Reynolds, C. J., Mirosa, M. ve Clothier, B. (2016). New Zealand's food waste: estimating the tonnes, value, calories and resources wasted. Agriculture, 6(1), 9.

Resmi Gazete (RG). (2020). Veteriner hizmetleri, bitki sağhlğgl, gıda ve yem kanunu. 15 Aralık 2020 tarihinde https://www.resmigazete.gov.tr/eskiler/2010/06/20100613-12.htm adresinden erişildi.

Richter, B. ve Bokelmann, W. (2016). Approaches of the German food industry for addressing the issue of food losses. Waste Management, 48, 423-429.

Rohini, C., Geetha, P. S., Vijayalakshmi, R., Mini, M. L. ve Pasupathi, E. (2020). Global effects of food waste. Journal of Pharmacognosy and Phytochemistry, 9(2), 690-699.

Ronson, D. ve Caraher, M. (2016). Food banks: Big society or shunting yards? Successful failures. Food poverty and insecurity: International food inequalities, 79-88.

Ross, M., Campbell, E. C. ve Webb, K. L. (2013). Recent trends in the nutritional quality of food banks' food and beverage inventory: Case studies of six California food banks. Journal of Hunger \& Environmental Nutrition, 8(3), 294-309.

Sayın, Z. (2013). Sosyal sorumluluk kapsamında gıda bankacılı̆̆ sistemi ve bir uygulama. Yayınlanmamış yüksek lisans tezi, Marmara Üniversitesi, İstanbul. 
Silahlı, O. (2020). Türk gıda projesi dünyaya örnek. 2 Ocak 2021 tarihinde https://www.milliyet.com.tr/gundem/turk-gida-projesi-dunyaya-ornek-2557859 adresinden erişildi.

Singh, R. P. ve Anderson, B. A. (2004). The major types of food spoilage: An overview. Understanding and Measuring the Shelf-life of Food, 3-23.

Stuart, T. (2009). Waste: Uncovering the global food scandal. NewYork: WW Norton \& Company.

Süzer, H. S. (2020). Türkiye'de bir ilk: Otomat Gıda Bankacilığı. 2 Ocak 2021 tarihinde https://www.serhansuzer.com/tr/turkiyede-bir-ilk-otomat-gida-bankaciligi adresinden erişildi.

Tarasuk, V., Dachner, N., Hamelin, A. M., Ostry, A., Williams, P., Bosckei, E., Poland, B. ve Raine, K. (2014). A survey of food bank operations in five Canadian cities. BMC Public Health, 14(1), 1234.

Tarasuk, V., St-Germain, A. A. F. ve Loopstra, R. (2020). The relationship between food banks and food insecurity: Insights from Canada. Voluntas: International Journal of Voluntary and Nonprofit Organizations, 31(5), 841-852.

TBMM. (2018). Türkiye Büyük Millet Meclisi. Genel kurul karar cetveli. 20, 1-132.

TOB. (2020). T.C. Tarım ve Orman Bakanlı̆̆ı. Gıdanı koru sofrana sahip çık. 18 Aralık 2020 tarihinde https://www.gidanikoru.com/ adresinden erişildi.

Tefera, T., Kanampiu, F., De Groote, H., Hellin, J., Mugo, S., Kimenju, S., Beyene, Y., Boddupalli, P. M., Shiferaw, B. ve Banziger, M. (2011). The metal silo: An effective grain storage technology for reducing post-harvest insect and pathogen losses in maize while improving smallholder farmers' food security in developing countries. Crop Protection, 30(3), 240-245.

Teron, A. C. ve Tarasuk, V. S. (1999). Charitable food assistance: What are food bank users receiving? Canadian Journal of Public Health/Revue Canadienne de Sante'e Publique, 90(6), 382-384.

TGDF. (2020). Türkiye Gıda ve İçecek Sanayii Dernekleri Federasyonu. Türkiye'de gıda israfı. 16 Aralık 2020 tarihinde https://www.tgdf.org.tr/ adresinden erişildi.

TIDER. (2020). Temel İhtiyaç Derneği. 8 Ekim 2020 tarihinde https://www.tider.org/ adresinden erişildi.

Urrutia, I., Dias, G. M. ve Clapp, J. (2019). Material and visceral engagements with household food waste: Towards opportunities for policy interventions. Resources, Conservation and Recycling, 150, 104435.

Vatansever Deviren, N. ve Kurtuluş, G. (2020). Yoksullukla mücadelede gida bankacılığının rolü. Journal of International Social Research, 13(73), 980-987.

Verghese, K., Lewis, H., Lockrey, S. ve Williams, H. (2015). Packagings role in minimizing food loss and waste across the supply chain. Packaging Technology and Science, 28(7), 603-620.

Vilariño, M. V., Franco, C. ve Quarrington, C. (2017). Food loss and waste reduction as an integral part of a circular economy. Frontiers in environmental science, 5, 1-5. 
Vos, R. (2019). Reducing food losses in developing countries: Simple technological solutions, complex adoption along supply chains. In J. V. Braun, M. S. Sorondo \& R. Steiner (Eds.). Reduction of food loss and waste 143-151. Roma: Libreria Editrice Vaticana.

Wie, S. ve Giebler, K. (2013). Nonfood-related challenges and resources affect functioning of food banks. Journal of Foodservice Business Research, 16(1), 76-84.

Wilson, N. L. W., Rickard, B. J., Saputo, R. ve Ho, S. T. (2017). Food waste: The role of date labels, package size, and product category. Food Quality and Preference, 55, 35-44.

Withanage, S. V., Dias, G. M. ve Habib, K. (2021). Review of household food waste quantification methods: Focus on composition analysis. Journal of Cleaner Production, 279, 123722.

Yuan, J. J., Yi, S., Williams, H. A. ve Park, O. H. (2019). US consumers' perceptions of imperfect "ugly" produce. British Food Journal, 121, 2666-2682. 